\section{Mast cells are an important cellular source of tumour necrosis factor $\alpha$ in human intestinal tissue}

S C Bischoff, A Lorentz, S Schwengberg, G Weier, R Raab, M P Manns

\begin{abstract}
Background-Several inflammatory disorders of the intestine are characterised by enhanced expression of tumour necrosis factor $\alpha($ TNF- $\alpha)$. Monocytes and macrophages have been suggested as a major cellular source of TNF- $\alpha$ in human gut, whereas mast cells, although known to be capable of producing TNF- $\alpha$, have been poorly examined in this respect.
\end{abstract}

Aims-To investigate whether human intestinal mast cells can produce TNF- $\alpha$, and which factors regulate TNF- $\alpha$ production in these cells.

Methods-Mast cells were isolated from surgery tissue specimens of patients undergoing bowel resection because of cancer. Immunohistochemical studies were performed in biopsy specimens derived from 13 patients (two healthy controls, four with Crohn's disease, four with ulcerative colitis, three others). TNF- $\alpha$ mRNA and protein expression were studied in vitro by polymerase chain reaction, RNAse protection assay, western blot, and enzyme linked immunosorbent assay in isolated purified human intestinal mast cells stimulated by IgE receptor crosslinking, intestinal bacteria, and lipopolysaccharide. Cellular localisation of TNF- $\alpha$ was examined by immunohistochemistry. Results-TNF- $\alpha$ mRNA and protein were expressed constitutively in isolated human intestinal mast cells. Expression of TNF- $\alpha$ mRNA and release of TNF- $\alpha$ protein were substantially enhanced by IgE receptor crosslinking and by coculture of mast cells with intestinal bacteria; lipopolysaccharide had only marginal effects. Immunohistochemical studies revealed that approximately $60 \%$ of the lamina propria cells with immunoreactivity for TNF- $\alpha$ were mast cells.

Conclusions-The data show that mast cells are an important source of TNF- $\alpha$ in the human intestinal mucosa.

(Gut 1999;44:643-652)

Keywords: tumour necrosis factor; mast cells; inflammatory bowel disease; bacteria

Transplant Surgery Medical School of

Hannover, D-30623

Hannover, Germany R Raab

Correspondence to: Dr Bischoff.

Accepted for publication 1 December 1998

Tumour necrosis factor $\alpha(\mathrm{TNF}-\alpha)$ is a multifunctional cytokine with many proinflammatory and immunoregulatory activities. ${ }^{12}$ It is a chemoattractant for neutrophils and monocytes, it increases microvascular permeability, and activates $\mathrm{T}$ cells, eosinophils, and mast cells of the skin. ${ }^{1-4}$ Moreover, TNF- $\alpha$ induces endothelial adhesion molecules and thus may initiate the recruitment of circulatory inflammatory cells into the tissue. ${ }^{4} \mathrm{TNF}-\alpha$ is produced by many cell types including monocytes, macrophages, $\mathrm{T}$ cells, eosinophils, and mast cells. ${ }^{156}$ In contrast to other cell types, it has been shown in rodents that mast cells store preformed TNF- $\alpha$ in significant quantities and release it on IgE dependent activation. ${ }^{6}$

A role of TNF- $\alpha$ has been implicated in the pathogenesis of acute inflammatory events caused by Gram negative bacterial infection and of chronic inflammatory disorders such as inflammatory bowel disease (IBD). ${ }^{1}{ }^{2}$ Interestingly, some evidence derived from animal studies suggests that TNF- $\alpha$, at low doses, renders a protective effect against bacterial infection, whereas high doses cause tissue destruction and severe clinical symptoms leading to fatal septic shock. ${ }^{78}$ In chronic inflammatory diseases, tissue levels of TNF- $\alpha$ are increased; this cytokine has therefore been targeted recently for treatment. Randomised, placebo controlled, double blind clinical trials showed that Crohn's disease and rheumatoid arthritis can be successfully treated by antagonising TNF- $\alpha$ with chimeric antihuman TNF- $\alpha$ antibody or TNF receptor Fc fusion protein. ${ }^{9}{ }^{10}$ These studies support the assumption of a fundamental clinical relevance of TNF- $\alpha$ in inflammatory disorders.

Mast cells are tissue cells that exert their biological effects by releasing preformed and de novo synthesised mediators such as histamine, proteases, leukotrienes, prostaglandins, and cytokines on cell activation by IgE receptor crosslinking and other less defined cellular signals. ${ }^{112}$ The role of human mast cells in mediating immediate type allergic reactions is well known. In addition, there is increasing evidence that mast cells are involved in chronic inflammatory processes such as IBD, autoimmune diseases, tissue remodelling, and fibrosis. ${ }^{11}{ }^{12}$ The recognition of mast cells as cytokine producing cells has extended their potential functions from proinflammatory effector cells to regulatory components of the immune system. ${ }^{11}$ One of the first cytokines found to be produced by mast cells was TNF- $\alpha$, which was detected primarily in rodent mast cells and mast cell lines. ${ }^{6}$ In animal models, mast cell derived TNF- $\alpha$ was found to
Abbreviations used in this paper: IBD,

inflammatory bowel disease; LPS, lipopolysaccharide; MC, mast cell; SCF, stem cell factor; sLT,

sulphidoleukotriene; TNF- $\alpha$, tumour necrosis factor $\alpha$. 
be responsible for the regulation of bacterial infection and for the influx of neutrophils observed during immune complex peritonitis and $\operatorname{IgE}$ dependent cutaneous or gastric inflammation. ${ }^{13-15}$ More recent studies indicated that TNF- $\alpha$ can be also synthesised by human mast cells of the skin, the lung, and the nasal mucosa during allergic responses. ${ }^{16-18}$ It is questionable whether such data can be extrapolated to the gastrointestinal mucosa, as mast cells derived from different species and different tissues were found to be heterogeneous in terms of morphological, immunohistochemical, and functional criteria. ${ }^{112}$ It is not known whether human intestinal mast cells are capable of producing $\mathrm{TNF}-\alpha$, and whether they contribute to the enhanced TNF- $\alpha$ levels found in IBD and other forms of chronic intestinal inflammation. Furthermore, the regulation of TNF- $\alpha$ synthesis and release in human mast cells is largely unclear. To address these questions, we performed immunohistochemical studies using intestinal biopsies and we studied TNF- $\alpha$ mRNA expression and protein release in vitro by human intestinal mast cells using recently established methods. ${ }^{19} 20$

\section{Methods}

PATIENTS

For mast cell isolation, human tissue was obtained from surgical specimens (macroscopically normal border sections, free of tumour cells as determined by histological examination of the tissue) of patients who underwent bowel resection because of intestinal cancer. For immunohistochemical studies, mucosal biopsy specimens derived from 13 patients (four Crohn's disease, four ulcerative colitis, three intestinal food hypersensitivity, two healthy controls) were examined.

CULTURE MEDIUM AND CELL STIMULI

Cell culture medium consisted of RPMI 1640 without phenol red supplemented with $10 \%$ ( $\mathrm{vol} / \mathrm{vol}$ ) heat inactivated fetal calf serum, 25 $\mathrm{mM}$ HEPES, $2 \mathrm{mM}$ L-glutamine, $100 \mu \mathrm{g} / \mathrm{ml}$ streptomycin, $100 \mu \mathrm{g} / \mathrm{ml}$ gentamycin, $100 \mathrm{U} / \mathrm{ml}$ penicillin, and $0.5 \mu \mathrm{g} / \mathrm{ml}$ amphotericin (all cell culture reagents were from Gibco Life Technologies, Paisley, UK). HEPES/albumin (HA) buffer contained $20 \mathrm{mM}$ HEPES (Sigma Chemicals, Steinheim, Germany), and $1 \mathrm{mg} / \mathrm{ml}$ bovine serum albumin (Sigma Chemical Co). Human recombinant stem cell factor (SCF) was purchased in lyophilised form (PreproTech Inc., Rocky Hill, New Jersey, USA) and reconstituted in HA buffer at $50 \mu \mathrm{g} / \mathrm{ml}$. Mast cells were stimulated by $\mathrm{IgE}$ receptor crosslinking using the purified monoclonal antibody 29C6 (final concentration $100 \mathrm{ng} / \mathrm{ml}$, provided by Hoffmann-La Roche, Nutley, New Jersey) directed against a non-IgE binding epitope of the high affinity $\operatorname{IgE}$ receptor $\alpha$ chain. $^{21}$ Lipopolysaccharide (LPS) prepared from the Escherichia coli strain 026:B6 (Sigma) was diluted to $1 \mathrm{mg} / \mathrm{ml}$ in distilled water and used at a final concentration of $10 \mu \mathrm{g} / \mathrm{ml}$. Ionomycin and phorbol myristate acetate (PMA) (both from Sigma) were used for cell activation at a final concentration of $1 \mu \mathrm{M}$ each. The final concentrations of mast cell agonists have been determined as maximally effective concentrations for mast cell activation in previous studies (data not shown). LPS was stored at $+4^{\circ} \mathrm{C}$. All other cell stimuli were stored at $-80^{\circ} \mathrm{C}$ in small aliquots to avoid freeze-thaw cycles.

ISOLATION AND PURIFICATION OF HUMAN INTESTINAL MAST CELLS

Human mast cells were isolated from intestinal tissue under sterile conditions by a four step enzymatic tissue dispersion method as described in detail previously. ${ }^{1320}$ The primary cell suspension obtained after cell isolation contained $50-150 \times 10^{6}$ cells, of which approximately $5 \%$ were mast cells. Cells were washed, resuspended in culture medium at a cell density of $2 \times 10^{6}$ cells, and cultured overnight in $250 \mathrm{ml}$ standard culture flasks. Mast cells were purified the following day provided that the primary cell suspension contained at least $2 \times 10^{6}$ mast cells. Enrichment of mast cells was achieved by positive selection of mast cells using magnetic cell separation (MACS system, Miltenyi Biotec, Bergisch Gladbach, Germany). ${ }^{20}{ }^{22}$ Unpurified cells (approximately $10^{8}$ cells) were harvested from the culture flasks, counted after staining with Tuerk's solution (Fluka, Buchs, Switzerland), sedimented by centrifugation $\left(300 \mathrm{~g}, 10\right.$ minutes, $\left.4^{\circ} \mathrm{C}\right)$, and resuspended in $250 \mu$ lof HA buffer containing $5 \mu \mathrm{g} / \mathrm{ml}$ monoclonal antibody YB5.B8 (Pharmingen, Hamburg, Germany) directed against human $c$-kit. ${ }^{23}$ Cells were incubated with the anti-c-kit monoclonal antibody for 30 minutes at $4^{\circ} \mathrm{C}$ with gentle agitation, washed and resuspended in $250 \mu \mathrm{l} \mathrm{HA}$ buffer, and then incubated for 30 minutes at $4^{\circ} \mathrm{C}$ with $50 \mu$ of goat antimouse IgG antibody coupled to paramagnetic beads (Miltenyi Biotec). After washing in HA buffer, mast cells were enriched by magnetic separation of the cells using a MACS BS column placed in a magnetic field. After separation, cells were washed in culture medium and counted. Cell viability was analysed by staining with trypan blue (Sigma). Percentage of mast cells was evaluated by differential count of cytocentrifuge smears stained with May-Grünwald/Giemsa (Riedel-de Haen, Seelze, Germany). Immunomagnetic separation of mast cells enhanced mast cells purity from $6(3) \%$ (range $3-13 \%$ ) to 70 (12)\% (range $50-86 \%$; $n=13, \mathrm{p}<0.001$ ). The recovery of mast cells was 52 (22)\%.

MAST CELL CULTURE AND STIMULATION

Purified mast cells were cultured in a humidified atmosphere containing $5 \% \mathrm{CO}_{2}$ at $37^{\circ} \mathrm{C}$ at a density of approximately $0.5 \times 10^{6}$ cells $/ \mathrm{ml}$ in culture medium supplemented with SCF (25 $\mathrm{ng} / \mathrm{ml}$ final concentration) using standard multiwell plastic plates. ${ }^{20}$ In the presence of SCF, mast cells were cultured for up to four weeks without evidence for decreased viability as suggested by morphology, trypan blue staining, and functional properties. The mean (SD) culture time was 13 (8) days (range 5-32 days). Without SCF supplementation, purified mast cells survived in culture for only a few days (data not shown). Cultured mast cells were fed 
A

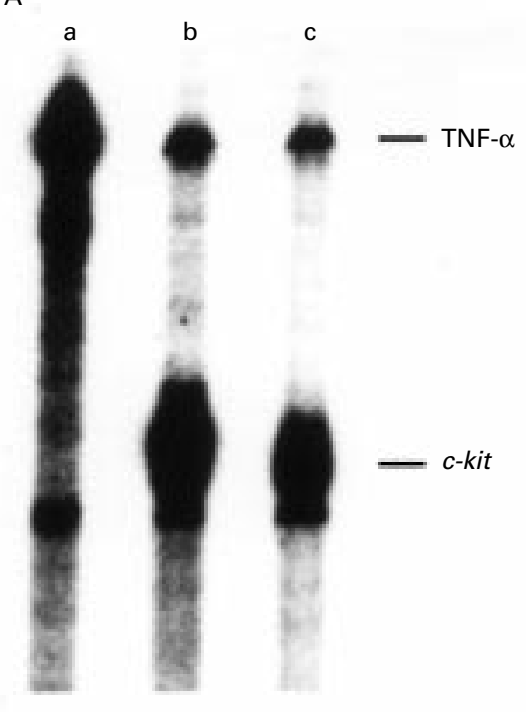

B

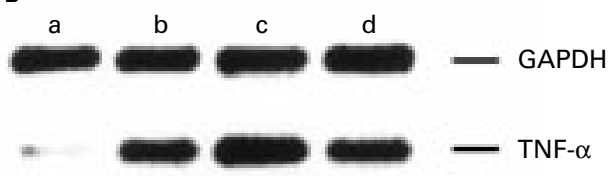

Figure 1 Expression of TNF-a mRNA in purified human intestinal mast cells. (A) RNAse protection assay: $10 \mu \mathrm{g}$ of total RNA from THP.1 cells stimulated with $300 \mathrm{U} / \mathrm{ml}$

IFN $\gamma($ a), and $8 \mu \mathrm{g}$ each of total RNA from unstimulated mast cells (b), and from mast cells stimulated with 100 $\mathrm{ng} / \mathrm{ml} 29 \mathrm{C6}$ (c), respectively (mast cell purity 98\%) were hybridised with radiolabelled TNF- $a$ cRNA $(a, b, c)$ and c-kit cRNA $(b, c)$. (B) Primer dropping RT-PCR: total RNA derived from purified mast cells (99\% purity) either unstimulated (a), or stimulated with $100 \mathrm{ng} / \mathrm{ml} 29 \mathrm{C6}$ (b), $4 \times 10^{6} / \mathrm{ml}$ bacteria (c), or $10 \mu \mathrm{g} / \mathrm{ml}$ LPS (d) was amplified in the presence of primer pairs for TNF- $\alpha$ and (after seven PCR cycles) GAPDH. DNA fragments obtained after 33 cycles are shown.

once a week by carefully exchanging half of the culture medium supplemented with SCF. The time interval between the last supplementation with culture medium containing SCF and start of mediator release experiments was at least five days. During cell culture, mast cell purity increased further to 91 (6) \% (range 76-100\%; $\mathrm{n}=13, \mathrm{p}<0.001$ ). After culture, mast cells were stimulated by different agonists such as monoclonal antibody 29C6, LPS, or intestinal bacteria (see below). Six hours after addition of the mast cell agonists, cells were separated from the supernatant by centrifugation $(300 \mathrm{~g}$, 10 minutes, $4^{\circ} \mathrm{C}$ ). The supernatants were stored at $-80^{\circ} \mathrm{C}$ for measurement of cytokines and mediators. Cell pellets were used for RNA and protein extraction.

\section{PREPARATION OF INTESTINAL BACTERIA}

In some experiments, a preparation of human intestinal bacteria was used for incubation with cultured mast cells. The preparation of bacteria was obtained from an endogenously infected human intestinal cell culture. The cells were isolated as described from a tissue specimen derived from a 33 year old male patient suffering from polyposis coli without evidence of enteritis or bacterial sepsis. Bacterial infection of mast cells cultured in medium supplemented with different antibiotics was rarely observed. However, in this case, a massive infection of the unpurified intestinal cells had already occurred after overnight culture, and the mast cells examined in the microscope seemed to be activated. The cell supernatants were collected after 16 hours of culture and contained approximately $10^{7}$ bacteria per $\mathrm{ml}$. Microbiological differentiation of the bacteria revealed a mixture of three Gram negative bacterial strains (Escherichia coli, Klebsiella oxytoca, and Stenotrophomonas maltophilia, formerly named Xanthomonas maltophilia). For experiments, bacterial suspensions were grown up to a density of $4 \times 10^{8}$ bacteria per ml. Mast cell cultures were challenged for six hours with intestinal bacteria at an initial concentration of $4 \times 10^{6}$ bacteria per ml. Despite supplementation of the culture medium with antibiotics, bacteria stayed alive but hardly expanded.

\section{MEASUREMENT OF MAST CELL MEDIATORS AND} CYTOKINES

Histamine was measured in cell free supernatants using a commercially available radioimmunoassay (Coulter-Immunotech, Krefeld, Germany). Sulphidoleukotrienes (sLT) were measured by radioimmunoassay as previously described. ${ }^{24}$ Histamine release was expressed as ng histamine per $10^{6}$ mast cells, sLT production as pg sLT per $10^{6}$ mast cells. TNF- $\alpha$ protein was quantified in cell supernatants by ELISA (R\&D Systems, Wiesbaden, Germany). The detection limit of the TNF- $\alpha$ ELISA was 5 $\mathrm{pg} / \mathrm{ml}$.

SDS-PAGE AND WESTERN BLOT

TNF- $\alpha$ protein was detected by western blot analysis in cell lysates of purified mast cells ( $>95 \%$ mast cells purity, $n=3$ ). Recombinant human TNF- $\alpha$ (0.5 $\mu \mathrm{g}$, PreproTech) was applied as standard protein. Amersham broad spectrum rainbow marker (Amersham, Little Chalfont, UK) was used as molecular weight marker. Mast cells $\left(10^{6}\right)$ were harvested and mixed with $10 \mu \mathrm{l}$ of double concentrated sample buffer (186 mM Tris/ $\mathrm{HCl}$ at $\mathrm{pH} \mathrm{6.8,20 \%}$ (wt/vol) glycerol, 4\% (wt/vol) sodium dodecyl sulphate (SDS), $0.005 \%$ (wt/vol) bromphenol blue, and $10 \%$ (vol $/ \mathrm{vol}) \beta$ mercaptoethanol), sonicated for five minutes, and boiled at $95^{\circ} \mathrm{C}$ for 10 minutes. Protein extracts were separated by SDS polyacrylamide gel electrophoresis (SDS-PAGE).

SDS-PAGE was performed using a mini gel system (Mini-Protean II Cell, Biorad, München, Germany) with $15 \%$ running and $5 \%$ casting gels $(0.75 \mathrm{~mm}$ thick) according to Laemmli. ${ }^{25}$ Samples were run at $100 \mathrm{~V}$ for at least two hours at room temperature. Proteins were then blotted on Trans-Blot nitrocellulose foil (Biorad) using a semidry blotting apparatus (Phase, Mölln, Germany) with $45 \mathrm{~mA} / \mathrm{gel}$ for 45 minutes. The blot foil was saturated in Tris buffered saline with $0.05 \%$ Tween 20 at $\mathrm{pH} 8.0$ containing $1 \%$ bovine serum albumin (TBST) 
at $4^{\circ} \mathrm{C}$ overnight with gentle agitation. A polyclonal rabbit antihuman $\mathrm{TNF}-\alpha$ antibody screened for western blots (Genzyme, Cambridge, Massachusetts, USA) was used as a primary antibody at a $1 / 250$ dilution in TBST for one hour at room temperature followed by a one hour incubation with a polyclonal antirabbit IgG antibody labelled with POD at a
1/2000 dilution (Amersham). Two negative controls were included. Firstly, the blot foil was incubated directly with the secondary antirabbit antibody to exclude cross reactivity; secondly, the primary antibody was replaced by a rabbit non-immune serum to exclude unspecific binding of rabbit antibodies to human proteins. The blot was developed with
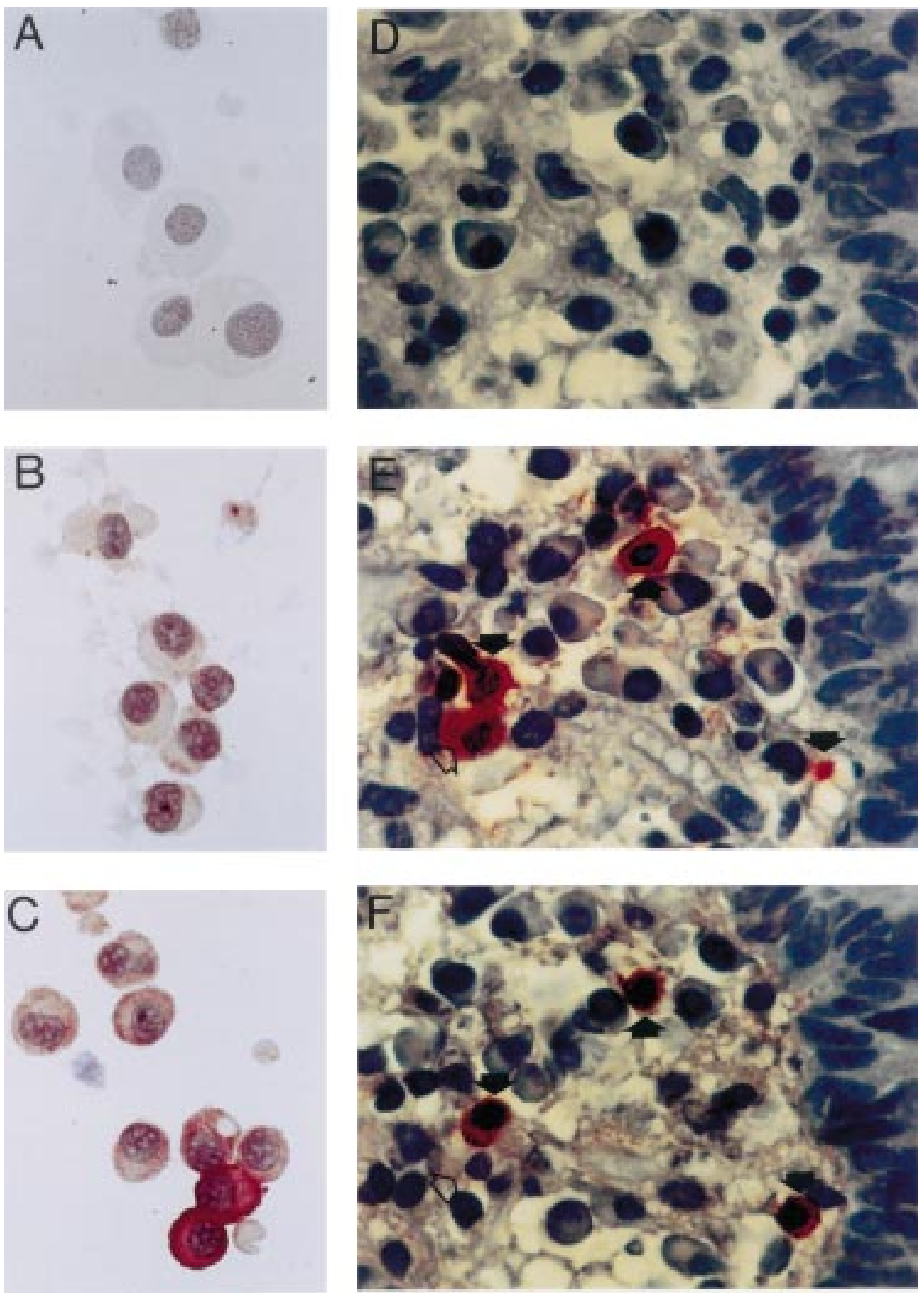

Figure 2 Immunostaining of human intestinal mast cells with anti-TNF- $\alpha$ antiserum (original magnification $\times 1000$ ). (A-C) Cytocentrifuge smears of purified mast cells. A, cytocentrifuge of a mast cell preparation containing $96 \%$ mast cells, negative control (staining with a non-immune control antiserum); $B$, same cells as in A, unstimulated mast cells (staining with rabbit antihuman TNF- $a$ antiserum, immunoreactive cells are stained); $C$, same cells as in $A$, stimulation of the mast cells by incubation with intestinal bacteria for six hours (staining as in $B$ ). $(D-F)$ Immunohistochemistry of intestinal tissue sections derived from a patient with active Crohn's disease using different primary antibodies. $D$, negative control using non-immune control antiserum; $E$, staining with antihuman tryptase monoclonal antibody; $F$, staining with antihuman TNF-a antiserum. Closed arrows indicate TNF-a positive mast cells, open arrow indicates a TNF- $a$ negative mast cell. 


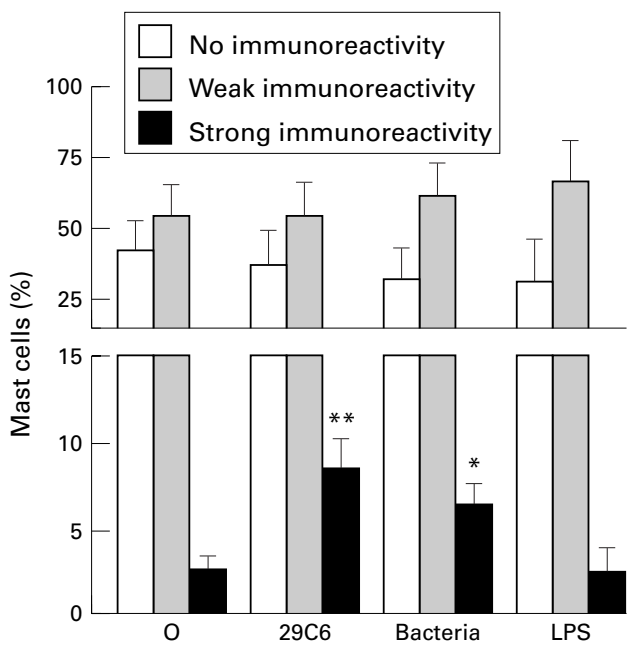

Figure 3 TNF-a immunoreactivity in isolated human intestinal mast cells. Cultured mast cells derived from seven cell preparations were challenged with buffer control $(O)$, 29 C6 (29C6), bacteria, or LPS. Mean (SD) percentages of mast cells with no (o), weak (+), and strong (++) immunoreactivity are shown. ${ }^{\star} p<0.05,{ }^{\star} p<0.01$ versus buffer control.

4-chloro-1-naphtol (Sigma) in phosphate buffered saline (PBS)/methanol.

RNA PREPARATION AND REVERSE TRANSCRIPTASE POLYMERASE CHAIN REACTION

Total RNA was prepared from human intestinal cell preparations containing $95-100 \%$ mast cells using the RNeasy Mini Kit (Qiagen, Hilden, Germany). A yield of approximately 3 $\mu \mathrm{g}$ total RNA was obtained from $10^{6}$ cells. For reverse transcriptase polymerase chain reaction (RT-PCR), $200 \mathrm{ng}$ of total RNA was treated for 15 minutes at $37^{\circ} \mathrm{C}$ with $10 \mathrm{U}$ RNAse-free DNAse (Promega, Madison, Wisconsin, USA) to remove genomic DNA. After denaturation for 10 minutes at $70^{\circ} \mathrm{C}, \mathrm{cDNA}$ was synthesised for one hour at $37^{\circ} \mathrm{C}$ by adding Superscript reverse transcriptase (Life Technologies, Eggenstein, Germany) and 20 pmol oligo dT primers (Pharmacia, Uppsala, Sweden). A 1/10 volume of the cDNA was used for one PCR reaction. PCR was performed with $2.5 \mathrm{U}$ Taq DNA polymerase (Life Technologies) and 20 pmol of the primers (synthesised by Life Technologies) for $c$-kit (sense: 5'-GGAGATCTGTGAGAATAGGCTC-3'; antisense: 5'-CCCATAGGACCAGACGTCACTTTC-3') and

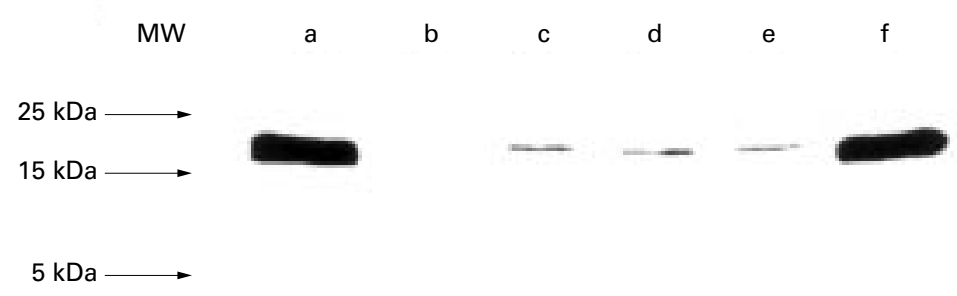

Figure 4 TNF-a protein in lysates of purified human intestinal mast cells. Recombinant human TNF- $\alpha(0.5 \mu \mathrm{g}$, lanes $a, f)$, culture medium without cells (lane $b)$, and lysates of $10^{6}$ mast cells purified to $96 \%$ (lanes $\left.c-e\right)$. Prior to cell lysis, mast cells had been challenged for six hours with buffer control (c), $29 C 6$ (d), or with intestinal bacteria (e). Arrows indicate the position of the molecular weight $(M W)$ markers. The $M W$ of the TNF- $a$ protein bands of mast cell samples corresponds to that of recombinant TNF-a $(17.9 \mathrm{kDa})$.
TNF- $\alpha$ (sense: 5'-GAGCTGAGAGATAACCAGCTGGTG-3'; antisense: 5'-CAGATAGATGGGCTCATACCAGGG-3') in a reaction volume of $50 \mu \mathrm{l}$. Positive controls were performed with primers for GAPDH (sense: 5'-ACCACAGTCCATGCCATCAC-3'; antisense: 5'-TCCACCACCCTGTTGCTGTA$\left.3^{\prime}\right)$. cDNA was amplified using a Peltier thermal cycler (PTC200, MJ Research, Watertown, Massachusetts, USA). Thirty five cycles (60 seconds at $94^{\circ} \mathrm{C}, 80$ seconds at $60^{\circ} \mathrm{C}, 70$ seconds at $72^{\circ} \mathrm{C}$ ) followed by a five minute extension at $72^{\circ} \mathrm{C}$ after the last cycle were performed. The PCR products contained transcripts of $354 \mathrm{bp}$ (c-kit), $237 \mathrm{bp}$ (TNF- $\alpha$ ), and $452 \mathrm{bp}$ (GAPDH), respectively. An aliquot of the PCR product $(10 \mu \mathrm{l})$ was separated on $1 \%$ agarose gel containing ethidium bromide (500 $\mathrm{ng} / \mathrm{ml}$ ) and photographed. To observe relative changes in mRNA expression of TNF- $\alpha$ the "primer dropping" method was used. ${ }^{26}$ Duplex PCRs were started in the presence of the primer pair for TNF- $\alpha$. After seven cycles the primer set of GAPDH was added. In each case, $10 \mu \mathrm{l}$ aliquots of the reactions taken after 29 cycles, 31 cycles, and 33 cycles were separated on $1 \%$ agarose gel containing ethidium bromide and analysed using an automated bioimaging analyser (Fuji BAS-1000, Raytest, Germany).

\section{RNASE PROTECTION ASSAY}

TNF- $\alpha$ RNA expression in human mast cells was examined using an RNAse protection assay (RNAse Protection Assay System from Promega). The mRNA derived from the human monocytic cell line THP-1 differentiated for 24 hours with $20 \mu \mathrm{M}$ PMA and stimulated for 24 hours with $300 \mathrm{U} / \mathrm{ml}$ interferon $\gamma$ (PreproTech) was used as a positive control. ${ }^{27}$ A $354 \mathrm{bp}$ fragment of $c$-kit cDNA obtained from a PCR reaction described above was subcloned into a plasmid (pCR-Script SK from Stratagene, La Jolla, California). A cDNA clone of TNF- $\alpha$ in pBluescript KS was kindly provided by C M Gelbmann and S Mestermann (University of Regensburg, Germany). The plasmids were linearised to synthesise radiolabelled antisense cRNA by adding $\alpha-{ }^{32} \mathrm{P}-$ UTP (3000 Ci/mmol, Hartmann Analytic, Braunschweig, Germany) and T7 RNA polymerase (Promega), resulting in specific activities of $1-2 \times 10^{9} \mathrm{cpm} / \mu \mathrm{g}$. RNA solution hybridisation was performed using a modified protocol of the manufacturer (Promega). Briefly, $8 \mu \mathrm{g}$ of total RNA was coprecipitated with $2 \times 10^{5} \mathrm{cpm}$ of freshly radiolabelled TNF- $\alpha$ and $c$-kit cRNA, and then redissolved in $20 \mu \mathrm{l}$ of $80 \%$ deionised formamide containing $1 \mathrm{mM}$ EDTA, $40 \mathrm{mM}$ PIPES, $\mathrm{pH}$ 6.4, and $0.2 \mathrm{M}$ sodium acetate. The mixture was denatured at $85^{\circ} \mathrm{C}$ for five minutes and then annealed at $50^{\circ} \mathrm{C}$ for 16 hours. After annealing, $180 \mu \mathrm{l}$ buffer containing $10 \mathrm{U}$ RNAse One (Promega) was added and incubated for one hour at room temperature to digest the unprotected riboprobes. The reaction was stopped by adding SDS to a final concentration of $1 \%$. The protected fragments were precipitated and separated on a $6 \%$ polyacrylamide urea gel. 

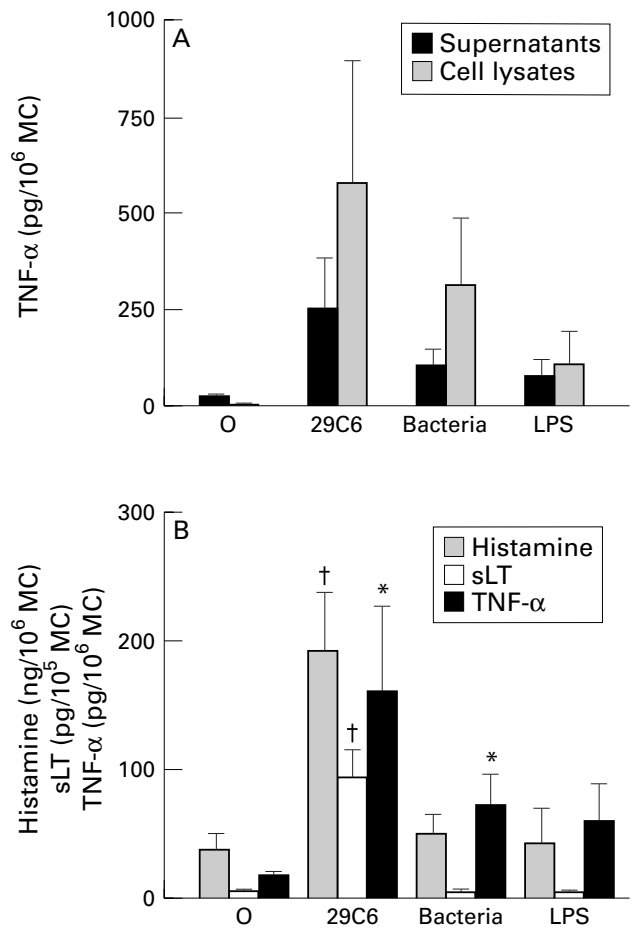

Figure 5 Production of $T N F-a$ and inflammatory mediators by human intestinal mast cells. (A)

Measurement of TNF-a in supernatants and cell lysates of mast cells, incubated for six hours with buffer control (O), mAb 29C6 (29C6), intestinal bacteria, or

lipopolysaccharide (LPS). (B) Measurement of TNF-a, histamine, and $s L T$ in supernatants of mast cells. ${ }^{\star} p<0.05$, $t p<0.005$ versus buffer control.

The results were analysed by a bioimaging analyser.

IMMUNOHISTOCHEMISTRY AND

IMMUNOCYTOCHEMISTRY

Mucosal biopsy specimens were fixed in paraformaldehyde $4 \%$ at $\mathrm{pH} 7.2$ for $18-24$ hours, embedded in paraffin wax, and sequentially sectioned at $3 \mu \mathrm{m}$. Sections were applied to slides coated with 3-aminopropyltriethoxysilan (APES) $0.5 \%$ in acetone (Sigma, Deisenhofen, Germany). Slides were dried overnight at $37^{\circ} \mathrm{C}$, deparaffinised, and hydrated. Endogenous peroxidase activity was blocked by hydrogen peroxide 3\% (10 minutes incubation at room temperature). Cultured cells were harvested, cytocentrifugated on slides, and fixed in acetone 50\%/methanol 50\% for 10 minutes and in ethanol $70 \%$ for 20 minutes. Cytospins were dried for 30 minutes and fixed by hydrogen peroxide 3\%/methanol $97 \%$. Immunostaining was performed using LSABKit Universal K680 (Dako Diagnostics, California, USA) for paraffin wax sections and Zymed LAB-SA System (Zymed Laboratories Inc., California, USA) for cytospins. ${ }^{20}{ }^{28}$ The primary antibodies used were mouse antihuman tryptase monoclonal antibody (IgG1; Chemikon, Temecula, California) at 0.28 $\mu \mathrm{g} / \mathrm{ml}$ or polyclonal rabbit antiserum directed against human TNF- $\alpha$ (Genzyme, Cambridge, Massachusetts) diluted $1 / 500$ in phosphate buffered saline (PBS). Controls were carried out with non-immune control serum diluted $1 / 500$ in PBS (Immunotech, Marseilles,
France) containing IgG1. Slides were counterstained with Mayer's haemalaun (E. Merck, Darmstadt, Germany) for one minute, blued in tap water for five minutes, and mounted in Kaiser's glycerol gelatine (E. Merck).

\section{ANALYSIS OF IMMUNOSTAINED SEQUENTIAL}

SECTIONS

Firstly, 500 lamina propria cells were differentiated to evaluate the percentage of tryptase positive cells (in section no. 1) and TNF- $\alpha$ positive cells (in section no. 2). Secondly, a visible field was selected at $\times 1000$ magnification in section 2, which contained cells staining positive for TNF- $\alpha$. This area was drawn on paper using a microscope with a drawing tube. Then, the corresponding area in adjacent sections 1 and 3 was adjusted and drawn on the same paper. Using this technique, we quantified lamina propria cells with immunoreactivity for TNF- $\alpha$, tryptase, or both, respectively. All immunostained sections and cytospins were evaluated by an observer who was not informed about the in vitro study protocols and the clinical data of the patients. We calculated the ratio between $\mathrm{TNF}-\alpha$ positive mast cells (Tryp+ TNF+) and total number of mast cells (Tryp+), and the ratio between TNF- $\alpha$ positive mast cells (Tryp+ TNF+) and total number of TNF- $\alpha$ positive cells (TNF+).

\section{STATISTICS}

Data were expressed as mean (SD), if not indicated otherwise. In addition, the 95\% confidence intervals $(95 \% \mathrm{CI})$ are quoted. The effects of agonists on mast cells were analysed for statistical significance (defined as $\mathrm{p}<0.05$ ) by the two tailed paired $t$ test (comparison with buffer control).

\section{Results}

TNF- $\alpha$ mRNA IS EXPRESSED IN ISOLATED HUMAN INTESTINAL MAST CELLS

TNF- $\alpha$ mRNA expression in human intestinal mast cells was analysed by RT-PCR in cell preparations containing $95-100 \%$ mast cells. The cells had been cultured in the presence of SCF at $25 \mathrm{ng} / \mathrm{ml}$ for 5-18 days $(\mathrm{n}=9$ experiments). Using RT-PCR analysis, TNF- $\alpha$ mRNA was detectable in all experiments. The RT-PCR signal for TNF- $\alpha$ was strongly enhanced if mast cells were stimulated for six hours by crosslinking the high affinity $\operatorname{IgE}$ receptor with 29C6 prior to cell harvesting and RNA preparation. We could confirm the RT-PCR results using the RNAse protection assay, which has been suggested as a valid method for RNA analysis and requires less amounts of RNA compared with Northern blotting. ${ }^{29}$ In this experiment, RNA was isolated from $3 \times 10^{6}$ cells ( $98 \%$ mast cells, $2 \%$ contaminating fibroblasts) and hybridised with radiolabelled TNF- $\alpha$ and $c-k i t$ cRNA. Figure $1 \mathrm{~A}$ shows that, based on measurements of radioactive signals using an automated bioimaging analyser, TNF- $\alpha$ mRNA was detectable in unstimulated mast cells, and that, in relation to $c$-kit mRNA levels, it increased twofold in mast cells stimulated with 29C6 for six hours. 

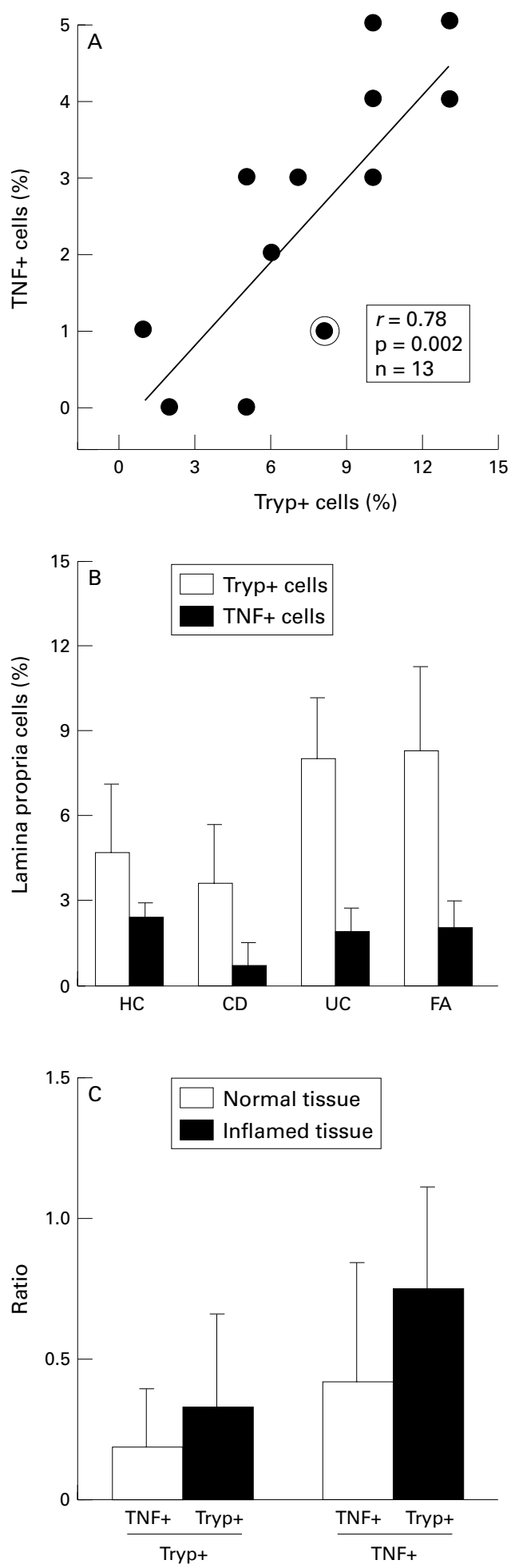

Figure 6 Expression of tryptase and $T N F-a$ by human intestinal lamina propria cells. Intestinal biopsy specimens were stained with monoclonal antibody directed against tryptase (Tryp+) and TNF-a (TNF+). (A) Tryp+ and TNF+ cells were counted in two adjacent tissue sections and the percentage of Tryp+ and TNF+ lamina propria cells was calculated ( $n=13$; the circled point represents two experiments with identical results). (B) Comparison of percentages of Tryp+ and TNF+ lamina propria cells in patients with Crohn's disease $(C D, n=4)$, ulcerative colitis (UC, $n=4)$, food allergy ( $F A, n=3)$, and healthy controls $(H C, n=2)$. (C) Ratio of TNF+ mast cells and mast cells (mast cells defined as Tryp+cells), and ratio of TNF+ mast cells and TNF+ cells, respectively, in histologically normal $(n=6)$ and inflamed tissue $(n=7)$.
The experiment was repeated once with a mast cell preparation containing $97 \%$ mast cells yielding almost identical results (not shown).

FACTORS ENHANCING TNF- $\alpha$ EXPRESSION BY HUMAN INTESTINAL MAST CELLS

We found that, apart from IgE receptor crosslinking, exposure of the cells for six hours to intestinal bacteria or to LPS also caused an enhancement of TNF- $\alpha$ mRNA expression. The primer dropping method established by Wong and colleagues ${ }^{26}$ was used to detect relative changes in TNF- $\alpha$ mRNA expression by mast cells cultured under different conditions. Total RNA was prepared from mast cells following stimulation for six hours with 29C6, LPS, or bacteria, respectively, and duplex PCR was performed as described in the Methods section. Figure 1B shows that stimulation with 29C6 or with LPS caused a fourfold increase in TNF- $\alpha$ mRNA expression compared with GAPDH mRNA expression. TNF- $\alpha$ mRNA expression was even more pronounced in mast cells incubated with intestinal bacteria (eightfold increase compared with unstimulated mast cells). The six hour time point for TNF- $\alpha$ mRNA analysis was the most appropriate one to compare the effects of bacteria and LPS with that of 29C6, as enhancement of TNF- $\alpha$ mRNA expression in response to bacteria and LPS was maximal after six hours. However, time course analysis revealed that the increase in TNF- $\alpha$ mRNA expression induced by $\operatorname{IgE}$ receptor crosslinking was already maximal after one hour (eightfold increase, data not shown).

These findings were confirmed by immunocytochemical studies showing that challenge of mast cells with 29C6 or intestinal bacteria caused an increase in mast cell percentages with a pronounced immunoreactivity after staining with anti-TNF- $\alpha$ antibody (fig 2 ). The quantitative evaluation of the cytocentrifuge smears derived from seven experiments revealed that, compared with buffer control (2.7 (2.0)\% mast cells with strong TNF- $\alpha$ immunoreactivity; 95\% CI $0.9-4.5 \%), 29 \mathrm{C} 6 \quad(8.5$ $(4.7) \% ; 4.1-12.9 \%)$ and intestinal bacteria (6.4 (3.5)\%; 3.1-9.6\%), but not LPS (2.5 (2.9) \%; 0-7.0\%), induced an enhancement of TNF- $\alpha$ immunoreactivity in mast cells (fig 3 ).

TNF- $\alpha$ protein expression was further examined by western blot and ELISA in mast cell lysates and supernatants. Figure 4 shows that TNF- $\alpha$ protein was detectable by western blot in lysates of unstimulated purified mast cells and of mast cells stimulated with 29C6 or intestinal bacteria. The size of the TNF- $\alpha$ protein detected in mast cell samples corresponded to that of recombinant TNF- $\alpha$ (17.9 $\mathrm{kD})$ and was located between the $15 \mathrm{kD}$ and 25 $\mathrm{kD}$ protein band of the molecular weight marker. No unspecific binding or cross reactivity of the antibodies used for the western blot were observed. Using this technique, no differences in TNF- $\alpha$ protein content could be found between the stimulation protocols. In contrast, measurement of TNF- $\alpha$ protein levels in mast cell lysates and supernatants by ELISA revealed substantial differences (fig 5A). 29C6 as well as bacteria caused an increase in $\mathrm{TNF}-\alpha$ 
protein content in mast cell lysates and supernatants. TNF- $\alpha$ release was most prominent after stimulation of the cells with 29C6. Whereas 29C6 induced significant release of both TNF- $\alpha$ and inflammatory mediators such as histamine and sLT, bacteria caused only $\mathrm{TNF}-\alpha$ release and LPS failed to induce significant release of any mediator (fig 5B).

TNF- $\alpha$ PROTEIN SYNTHESIS AND RELEASE BY

HUMAN INTESTINAL MAST CELLS IN VIVO

Mucosal biopsy specimens obtained from 13

patients (four with Crohn's disease, four with ulcerative colitis, three with intestinal food hypersensitivity, two healthy controls) were examined by immunohistological means for TNF- $\alpha$ and tryptase expression in sequential sections (fig 2). Figure 6A shows that the number of tryptase-positive cells (7.5 (3.7)\% of lamina propria cells; 95\% CI 5.8-9.8\%; $\mathrm{n}=13$ ) counted in section 1 correlated with the number of TNF- $\alpha$ positive cells $(2.5$ (1.8)\%; $1.4-3.5 \% ; \mathrm{n}=13)$. Analysis of sequential sections revealed that $60 \quad(40) \% \quad(95 \%$ CI $35-84 \%$ ) of the TNF- $\alpha$ positive cells within the lamina propria were tryptase positive mast cells, and $26(28) \%$ (95\% CI 10-43\%) of the mast cells were positive for TNF- $\alpha$. No significant differences in numbers of tryptase positive cells $(p=0.07$, one way analysis of variance) and TNF- $\alpha$ positive cells $(p=0.12)$ were found between healthy controls and patients with Crohn's disease, ulcerative colitis, and food allergy (fig 6B). As not all biopsy specimens derived from patients had histological signs of active inflammation such as epithelial destruction and leucocyte infiltration, specimens were divided into histologically normal $(n=6$; two healthy controls, one Crohn's disease, three food allergy) and inflamed ( $n=7$; three Crohn's disease, four ulcerative colitis) biopsy specimens. The numbers of tryptase positive cells and TNF- $\alpha$ positive cells, respectively, were similar in histologically inflamed and normal tissue. However, the percentages of TNF- $\alpha$ positive mast cells and the percentage of tryptase positive TNF producing cells were slightly higher in inflamed tissue compared with macroscopically normal tissue, although the differences were not statistically significant ( $t$ test, $\mathrm{p}>0.05$; fig $6 \mathrm{C}$ ).

\section{Discussion}

Our data indicate that human intestinal mast cells are a major source of TNF- $\alpha$ in the gastrointestinal tract. Furthermore, they extend previous studies showing that human mast cells of the skin and the respiratory tract are capable of producing TNF- $\alpha$ both in vitro on stimulation by $\mathrm{IgE}$ receptor crosslinking and in vivo in the course of allergic and other mast cell associated diseases to those from the human gastrointestinal tract. ${ }^{17-19}$ The knowledge that mast cells can synthesise and release TNF- $\alpha$ was based originally on findings in rodents and had to be confirmed for the human system, as many previous studies showed that rodent mast cells and human mast cells may differ substantially in functional respects. ${ }^{6}{ }^{11}$ For example, rodent mast cells express the interleukin 3 (IL-3) receptor and IL-3 is an important growth factor for rodent mast cells, whereas human mast cells lack the IL-3

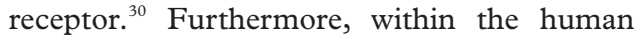
system, mast cells exert a considerable heterogeneity based on morphological, biochemical, and functional criteria. According to the protease content, three types of human mast cells (MC) have been described $\left(\mathrm{MC}_{\mathrm{T}}\right.$, containing tryptase but no chymase; $\mathrm{MC}_{\mathrm{TC}}$, containing both tryptase and chymase; and $\mathrm{MC}_{\mathrm{C}}$, containing chymase but no tryptase), which are present in various degrees in the intestinal tract (mucosa, $58 \% \mathrm{M}_{\mathrm{T}}, 35 \% \mathrm{MC}_{\mathrm{TC}}$, $7 \% \quad \mathrm{MC}_{\mathrm{C}} ;$ submucosa, $83 \% \quad \mathrm{MC}_{\mathrm{TC}}, 17 \%$ $\left.\mathrm{MC}_{\mathrm{C}}\right){ }^{31}$ Recently, it was shown that the classification of mast cells into different phenotypes may be of functional relevance, as $\mathrm{MC}_{\mathrm{TC}}$ produce cytokines (preferentially IL-4) other than $M_{\mathrm{T}}$ (IL-5 and IL-6). ${ }^{32}$ It is unclear whether the production of TNF- $\alpha$ can also be attributed to a particular mast cell subtype, as intestinal mast cell preparations contain different mast cell subtypes, which cannot be separated in vitro. However, it is tempting to speculate that both $\mathrm{MC}_{\mathrm{TC}}$ and $\mathrm{MC}_{\mathrm{T}}$ may produce TNF- $\alpha$, because human skin mast cells (which consist almost exclusively of $\mathrm{MC}_{\mathrm{TC}}$ ) and rodent gastral mast cells (which are believed to be equivalents of human $\mathrm{MC}_{\mathrm{T}}$ ) have been shown to produce TNF- $\alpha{ }^{16}{ }^{17}$

To date, the ability of gastrointestinal mast cells to produce cytokines such as TNF- $\alpha$ has hardly been studied. Apart from a study by Beil et al, who showed by electron microscopy that in Crohn's disease TNF- $\alpha$ immunoreactivity was localised in intestinal mast cells, we are not aware of studies examining cytokine production in human intestinal mast cells. ${ }^{33}$ This is surprising, as it is known from many studies that TNF- $\alpha$ is expressed in human gastrointestinal mucosa, and that the expression is strongly enhanced in the course of inflammatory diseases such as Crohn's disease or ulcerative colitis. ${ }^{2435}$ TNF- $\alpha$ production in the human gut has been attributed to monocytes, macrophages, natural killer cells, and $\mathrm{T}$ lymphocytes, but not to mast cells. ${ }^{1235}$ Our immunohistochemical studies, however, clearly show that human mucosal mast cells produce TNF- $\alpha$. We found no significant differences in TNF immunoreactivity between IBD patients and controls, which does not contradict previous findings, as immunohistochemistry is a delicate method for quantitative studies, and the number of patients we examined was rather small. Of particular interest is our finding that approximately $60 \%$ of all lamina propria cells expressing TNF- $\alpha$ protein were mast cells, which indicates that mast cells are of considerable relevance within the cell types producing TNF- $\alpha$ in the human intestinal mucosa. It is unclear at present, to what extent mast cells besides other cell types contribute to an enhanced $\mathrm{TNF}-\alpha$ production in inflammatory disease states. This may differ depending on the aetiology of the inflammatory disorder. ${ }^{7} 816$

To address the question of how TNF- $\alpha$ production is regulated in human intestinal mast cells, we performed in vitro studies with 
isolated purified mast cell preparations. We found that not only $\operatorname{IgE}$ receptor crosslinking by anti-IgE receptor antibody, as shown previously in rodent mast cells ${ }^{636}$ and human skin mast cells, ${ }^{17}{ }^{37}$ but also bacterial products activate human intestinal mast cells for enhanced $\mathrm{TNF}-\alpha$ production. The first evidence for the induction of TNF- $\alpha$ synthesis in mast cells by bacterial products came from animal studies. ${ }^{78}$ Malaviya et al, who infected animals with a mouse virulent strain of Klebsiella pneumoniae, found that purified mouse mast cells release $\mathrm{TNF}-\alpha$ on incubation with bacteria and that the type 1 fimbrial subunit, $\mathrm{FimH}$, was the necessary enterobacterial component for mast cell activation. ${ }^{8}$ We incubated human intestinal mast cells with a preparation containing the enterobacterial strains Escherichia coli, Klebsiella oxytoca, and Stenotrophomonas maltophilia, and found that these bacteria significantly enhance the synthesis of TNF- $\alpha$. Similar to 29C6, which crosslinks the high affinity IgE receptor on mast cells, the bacteria induced an increase in both TNF- $\alpha$ mRNA expression and protein synthesis and release. It is unclear whether bacterial antigen triggers mast cells by binding to and crosslinking surface bound $\mathrm{IgE}$ molecules or by IgE independent mechanisms. The fact that the mast cells used for experiments were isolated by enzymatic digestion of intestinal tissue and cultured for several days prior to stimulation, makes it unlikely that they have preserved IgE molecules on their surface and hence suggests an IgE independent mechanism. This hypothesis is supported by the finding that the bacterial product LPS was also capable of enhancing TNF- $\alpha$ mRNA expression, but no significant $\mathrm{TNF}-\alpha$ protein release, in human intestinal mast cells. LPS is also known to activate monocytes and macrophages for the production of TNF, and therefore represents an important factor regulating $\mathrm{TNF}-\alpha$ production in different cell types in an $\operatorname{IgE}$ independent manner. ${ }^{38}$ Apart from LPS, other bacterial derived factors seem to be involved in the regulation of $\mathrm{TNF}-\alpha$ in mast cells.

In previous studies, we and others have shown that IgE receptor crosslinking causes the release of inflammatory mediators such as histamine or leukotrienes from human mast cells, and that the release reaction is enhanced in the presence of SCF, the $c$-kit ligand. ${ }^{13}{ }^{39}$ Here we found that the release of preformed histamine and de novo synthesised sLT one the one hand, and TNF- $\alpha$ on the other, is regulated differently in human intestinal mast cells. 29C6 caused the release of histamine, sLT, and TNF- $\alpha$, whereas bacteria caused TNF- $\alpha$ release, but no sLT and only marginal histamine release. Similar results were reported for rat peritoneal mast cells which produce IL-6, but only marginal histamine release in response to LPS. ${ }^{40}$ SCF neither caused nor enhanced TNF- $\alpha$ release (data not shown), confirming previous studies performed in rat mast cells. ${ }^{41}$ The hypothesis of a different regulation of TNF- $\alpha$ and histamine/sLT release in mast cells is supported by the recent study of Tashiro et al who showed that in murine mast cells triggered by $\operatorname{IgE}$ receptor crosslinking, the secretion of
TNF- $\alpha$, but not of histamine or eicosanoids, is enhanced by costimulation of the cells via the CD 28 molecule. $^{36}$

The clinical consequences of TNF- $\alpha$ production by human intestinal mast cells are yet unclear. TNF- $\alpha$ may have beneficial as well as pathological functions depending on its concentration and on the kind of disease. Some studies performed in mouse models of acute bacterial infection, which have to be confirmed for the human situation, indicate a protective role of TNF- $\alpha$ derived from mast cells, whereas TNF- $\alpha$ is believed to be responsible for tissue infiltration with neutrophils and other inflammatory cells and subsequent tissue destruction in the course of chronic inflammatory diseases such as IBD. ${ }^{278}$ Several studies derived from the rodent system indicate that the production of TNF- $\alpha$ by mast cells can be influenced by pharmacological interventions, which suggests new strategies for the treatment of diseases associated with mast cells and TNF- $\alpha$. For example, it was shown that IL-10 inhibits TNF- $\alpha$ production in mast cells without affecting preformed histamine release. ${ }^{42}{ }^{43}$ This may be of particular interest for IBD, as preliminary clinical trials have been carried out showing that patients with Crohn's disease can be successfully treated by parenteral administration of IL-10. ${ }^{44}$ Furthermore, the classical drugs used for treatment of IBD, glucocorticosteroids and sulphasalazine, as well as interferon, also inhibit $\operatorname{IgE}$ dependent release of TNF- $\alpha$ and mediators by mast cells. ${ }^{45-47}$ These studies provide new insights into the mode of action of some drugs and, if the findings can be confirmed in future studies for human mast cells, they may be of particular clinical relevance for the treatment of allergic and other inflammatory diseases.

The authors thank Ms Anita Schmeil for technical assistance, Dr Michael Martin, Department of Molecular Pharmacology, for measurement of cytokines, and Dr Susanne Häusler, Department of Microbiology, for characterisation of intestinal bacteria. The study was supported by grant no SFB280-C8 from the Deutsche Forschungsgemeinschaft to SCB.

1 Bazzoni F, Beutler B. The tumor necrosis factor ligand and receptor families. N Engl f Med 1996;334:1717-25.

2 Van Deventer SJH. Tumor necrosis factor and Crohn's disease. Gut 1997;40:443-8

3 Van Overfeld FJ, Jorens PG, Rampart M, et al. Tumor necrosis factor stimulates human skin mast cells to release histamine and tryptase. Clin Exp Allergy 1991;21:711-14.

4 Paleolog EM, Delasalle SA, Buurman WA, et al. Functional activities of tumor necrosis factor alpha on human vascular endothelial cells. Blood 1994;84:2578-90.

5 Costa JJ, Matossian K, Resnick MB, et al. Human eosinophils can express the cytokines tumor necrosis factor- $\alpha$ and macrophage inflammatory protein-1 $\alpha$. f Clin Invest 1993;91:2673-84.

6 Gordon JR, Galli SJ. Release of both preformed and newly synthesized tumor necrosis factor- $\alpha$ (TNF $\alpha$ )/cachexin by synthesized tumor necrosis factor- $\alpha(\mathrm{TNF} \alpha) /$ cachexin by
mouse mast cells stimulated via the Fc $\mathrm{Fc}_{\varepsilon} \mathrm{RI}$. A mechanism mouse mast cells stimulated via the $\mathrm{Fc}_{\varepsilon} \mathrm{RI}$. A mechanism
for the sustained action of mast cell-derived TNF $\alpha$ during for the sustained action of mast cell-derived TNF $\alpha$ during IgE-dep $103-7$.

7 Echternacher B, Mannel DN, Hultner L. Critical protective role of mast cells in a model of acute septic peritonitis. Nature 1996;381:75-7.

8 Malaviya R, Ikeda T, Ross E, Abraham SN. Mast cell modulation of neutrophil influx and bacterial clearance at sites of infection through TNF-alpha. Nature 1996;381:7780.

9 Targan SR, Hannauer SB, van Deventer SJH, et al. A shortterm study of chimeric monoclonal antibody cA2 to tumor necrosis factor $\alpha$ for Crohn's disease. $N$ Engl $\mathcal{f} \mathrm{Med}$ 1997;337:1029-35.

10 Moreland LW, Baumgartner SW, Schiff MH, et al. Treatment of rheumatoid arthritis with a recombinant
human tumor necrosis factor receptor (p75)-Fc fusion human tumor necrosis factor receptor
protein. N Engl $\mathcal{F}$ Med 1997;337:141-7. 
11 Galli SJ. New concepts about the mast cell. $N$ Engl $\mathcal{F}$ Med 1993;328:257-65.

12 Bischoff SC. Mucosal allergy: role of mast cells and eosinophil granulocytes in the gut. Ballieres Clin Gastroenterol 1996;10:443-59.

13 Furuta GT, Schmidt-Choudhury A, Wang MY, et al. Mast cell-dependent tumor necrosis factor $\alpha$ production participates in allergic gastric inflammation in mice. Gastroenterology 1997;113:1560-9.

14 Zhang Y, Ramos B, Jakschik BA. Neutrophil recruitment by tumor necrosis factor from mast cells in immune complex peritonitis. Science 1992;258:1957-9.

15 Wershil BK, Wang ZS, Gordon JR, et al. Recruitment of neutrophils during IgE-dependent cutaneous late phase reactions in the mouse is mast cell-dependent. $f$ Clin Invest 1991;87:446-53.

16 Bradding P, Mediwake R, Feather ICH, et al. TNF alpha is localized to nasal mucosal mast cells and is released in acute allergic rhinitis. Clin Exp Allergy 1995;25:406-15.

17 Walsh LJ, Trinchieri G, Waldorf HA, et al. Human dermal mast cells contain and release tumor necrosis factor alpha, which induces endothelial leukocyte adhesion molecule 1 . Phich induces endothelial leukocyte adh

18 Bradding P, Roberts JA, Britten KM, et al. Interleukins (IL) $-4,-5,-6$, and TNF- $\alpha$ in normal and asthmatic airways: evidence for the human mast cell as a source of these cytokines. Am f Respir Cell Mol Biol 1994;10:471-80.

9 Bischoff SC, Schwengberg S, Wordelmann K, et al. Effect of $c$-kit ligand, stem cell factor, on mediator release by human intestinal mast cells isolated from patients with inflammatory bowel disease and controls. Gut 1996;28:104-14.

20 Bischoff SC, Schwengberg S, Raab R, et al. Functional properties of human intestinal mast cells cultured in a new culture system: enhancement of $\mathrm{IgE}$ receptor-dependent mediator release and response to stem cell factor. $\mathscr{F}$ Immunol 1997;159:5560-7.

21 Riske F, Hakimi J, Mallamaci M, et al. High affinity human IgE receptor (FcERI). Analysis of functional domains of the IgE receptor (FcERI). Analysis of functional domains of the a subunit with mo

22 Okayama Y, Hunt TC, Kassel O, et al. Assessment of the anti-c-kit monoclonal antibody YB5.B8 in affinity magnetic enrichment of human lung mast cells. F Immunol Method 1994;169:153-61.

23 Lerner NB, Nocka KH, Cole SR, et al. Monoclonal antibody YB5.B8 identifies the human c-kit protein product. Blood 1991;77:1876-83.

24 Bischoff SC, Dahinden CA. Effect of nerve growth factor on the release of inflammatory mediators by mature human basophils. Blood 1992;79:2662-9.

25 Laemmli UK. Cleavage of structural proteins during the assembly of the head of bactriophage T4. Nature 1970;227: $680-5$

26 Wong $\mathrm{H}$, Anderson WD, Cheng T, et al. Monitoring mRNA expression by polymerase chain reaction: the "primer expression by polymerase chain reaction: the "p

27 Kremlev SG, Umstead TM, Phelps DS. Surfactant protein A regulates cytokine production in the monocytic cell line A regulates cytokine production in the monocyt

28 Bischoff SC, Wedemeyer J, Herrmann A, et al. Quantitative assessment of intestinal eosinophils and mast cells in assessment of intestinal eosinophils and mast cells in

29 Stalder AK, Campbell IL. Simultaneous analysis of multiple cytokine receptor mRNAs by RNAse protection assay in LPS-induced endotoxemia. Lymphokine Cytokine Res 1994 13:107-12.
30 Valent P, Besemer J, Sillaber C, et al. Failure to detect IL-3binding sites on human mast cells. F Immunol 1990;145: 3432-7.

31 Weidner N, Austen KF. Heterogeneity of mast cells at multiple body sites. Path Res Pract 1993;189:156-62.

32 Bradding P, Okayama Y, Howarth PH, et al. Heterogeneity of human mast cells based on cytokine content. F Immunol 1995; 155:297-307.

33 Beil WJ, Weller PF, Peppercorn MA, et al. Ultrastructural immunogold localization of subcellular sites of TNF-alpha in colonic Crohn's disease. 7 Leukoc Biol 1995;58:284-98.

34 Murch SH, Braegger CP, Walker-Smith JA, et al. Location of tumour necrosis factor a by immunohistochemistry in
chronic inflammatory bowel disease. Gut 1993;34:1705-9.

35 Reinecker HC, Steffen M, Witthoeft T, et al. Enhanced secretion of tumour necrosis factor-alpha, IL-6, and IL-1 $\beta$ by isolated lamina propria mononuclear cells from patients with ulcerative colitis and Crohn's disease. Clin Exp Immunol 1993;94:174-81.

36 Tashiro M, Kawakami Y, Abe R, et al. Increased secretion of TNF- $\alpha$ by costimulation of mast cells via CD28 and FceRI. F Immunol 1997;158:2382-9.

37 Benyon RC, Bissonnette EY, Befus AD. Tumor necrosis factor- $\alpha$ dependent cytotoxicity of human skin mast cells is enhanced by anti-IgE antibodies. F Immunol 1991;147: 2253-8.

38 Mattson E, Van Dijk H, Van Kessel K, et al. Intracellular pathways involved in tumor necrosis factor- $\alpha$ release by human monocytes on stimulation with lipopolysaccharide or staphylococcal peptidoglycan are partly similar. F Infect Dis 1996;173:212-18.

39 Bischoff SC, Dahinden CA. C-kit ligand: a unique potentiator of mediator release by human lung mast cells. $\mathcal{F}$ Exp Med 1992;175:237-44.

40 Leal-Berumen I, Conlon P, Marshall JS. IL-6 production by rat peritoneal mast cells is not necessarily preceded by histamine release and can be induced by bacterial lipopolysaccharide. F Immunol 1994;152:5468-76.

41 Lin TJ, Bissonnette EY, Hirsh A, et al. Stem cell factor potentiates histamine secretion by multiple mechanisms, but does not affect tumour necrosis factor- $\alpha$ release from rat mast cells. Immunology 1996;89:301-7.

42 Marshall JS, Leal Berumen I, Nielsen L, et al. Interleukin (IL)-10 inhibits long-term IL-6 production but not preformed mediator release from rat peritoneal mast cells. preformed mediator release fron

43 Arock M, Zuany-Amorim C, Singer M, et al. Interleukin-10 inhibits cytokine generation from mast cells. Eur $\mathcal{F}$ Immunol 1996;26:166-70.

44 Van Deventer SJH, Elson CO, Fedorak RN. Multiple doses of intravenous interleukin 10 in steroid-refractory Crohn's disease. Gastroenterology 1997;113:383-9.

45 Eklund KK, Humphries DE, Xia Z, et al. Glucocorticoids inhibit the cytokine-induced proliferation of mast cells, the high-affinity IgE receptor-mediated expression of TNF- $\alpha$, and the IL-10-induced expression of chymases. $\mathcal{F}$ Immunol 1997;158:4373-80.

46 Bissonnette EY, Enciso JA, Befus AD. Inhibitory effects of sulfasalazine and its metabolites on histamine release and sulfasalazine and its metabolites on histamine release and 23.

47 Bissonnette EY, Chin B, Befus AD. Interferons differentially regulate histamine and TNF-a in rat intestinal mucosal mast cells. Immunology 1995;86:12-17. 